\title{
CANNIBALISM AMONG LEPIDOPTEROUS LARVAE
}

\author{
V. G. Dethier
}

Biological Laboratories, Harvard University

The occurrence of the carnivorous habit in lepidopterous larvæ is known in certain rather widely separated groups, one of which, the Lycænidæ, is outstanding (Brues, 1936). It is known also that some phytophagous larvæ will become carnivorous for a period of time either regularly or in the absence of a plentiful food supply (Brues, 1920). I have observed this and also cannibalism many times while breeding various species. ${ }^{1}$ A few examples may be cited.

When larvæ of the Arctiid, Apantesis arge Drury, were confined to a limited area (three to four larvæ to eight square inches) with a moderate supply of food, the smallest, least healthy, or least active larva was usually attacked while still alive and almost entirely eaten by a more robust specimen. Fifty of these larvæ were divided into lots of two, three, and four, each lot being limited to an area of eight square inches. In nearly seventy-five percent of all cases cannibalism occurred. It was noted more frequently when four larvæ were confined together or when one larva was smaller or weaker than its neighbors, as stated above. Moore (1912) reported that Phobis eubule L., when confined even in the presence of an ample food supply, ate smaller larvæ of its own species. The more aggressive individuals also devoured the more peaceful ones. Perkins (1928) found that Nemoria viridata L. in the presence of an abundance of food also showed cannibalistic tendencies. The larvæ from a large batch of eggs feasted upon one another till there was but one left. This animal pupated and a normal adult emerged. Subsequent breedings with other batches of eggs of the same species revealed no further cases of cannibalism.

I have observed that larvæ of Estigmene acræa Drury and Diacrisia virginica Fab. when confined with those of other

${ }^{1}$ For cases of oöphagy see Schultz $(1928,1935)$. 
species, notably Papilio polyxenes Fab., P. philenor L., and Danaus plexippus L., in ample space but with a limited food supply, readily attacked and ate pupating larvae and chrysalids of the butterflies. They also ate pupæ of their own species, devouring all the hair and silk of the cocoon as well. Papilio philenor L. speedily attacked chrysalids and pupating larvæ of its own species as soon as the food supply dried up or diminished. This has also been reported by Clark (1925) as occurring in P. polyxenes Fab. and Danaus plexippus L. Orfila (1927) reported that Ecpantheria indecisa Walkr. in the presence of an abundance of food devoured chrysalids of Tatochila autodice $\mathrm{Hb}$. and also the parasites (Apanteles sp?) with which the chrysalids were infected.

The most striking example that I observed was the case of a noctuid, Autographa sp?, which attacked other larvæ of its own species although plenty of food was available. It is interesting to note that this noctuid also fiercely attacked healthy and active larvæ of Danaus plexippus L. and Malacosoma americanum Fab. While the victim struggled the noctuid stood upon it and chewed its way rapidly into the flesh.

Bell is quoted (de Niceville 1901) as being of the opinion that a larva will never eat another larva feeding on a food plant different from its own. He also advanced the idea that "-cannibal larvæ are hardly conscious that they are eating up each other, being only guided to their proper food by the sense of taste, or possibly to a less extent by the sense of smell". The noctuid referred to above could not be induced to feed either upon cherry (the food plant upon which $M$. americanum was feeding) or upon milkweed (the food plant of D. plexippus) although it would feed upon other plants. The question had been raised by Bird (1925) as to whether or not the food plant imparted a flavor to larvæ which was repellent to internal parasites (the conditions would be the same in the case of cannibals). Whether or not this is the case can not be definitely stated at the present time. Undoubtedly the gut of the larva attacked would, if it contained food, taste of the food plant which had been eaten. It appears unlikely that the cannibal larva would be able to distinguish its prey before it had attacked it, and, therefore, 
should, theoretically, attack any larva regardless of what it had eaten.

v. Roesel v. Rosenhof (1749) reported that Chariclea delphinii L. frequently ate larvæ of its own species. Calyminia trapexzina (L.) and Agrotis ypsilon (Rott.) have been reported to be cannibalistic by Berg $(1875,1892)$. Lederer (1932) reports the case of a noctuid, Scopelosoma satellitia L., attacking and eating the posterior end of its own body. It is known that some larvae when injured in this region of the body will devour themselves. Schultz (1935) reports that the following larvæ ate chrysalids of their own species: Acidalia herbariata F., Eupithecia castigata Hb., and Dianthocia capsincola $\mathrm{Hb}$. He further states that Arctiidæ commonly nibble at chrysalids and that Caradrina exidua is cannibalistic.

Mr. C. M. Williams (unpublished data) noticed that when Hæmorrhagia thysbe Fab. larvæ were crowded some would attempt to eat others. He also noticed when many Telea polyphemus Cramer larvæ were crowded in confinement with an ample supply of their food plant that certain individuals attacked others and succeeded in breaking through the integument. In neither case, however, was the attack carried beyond this point.

Another interesting case is that of a larva of Epizeuxis lubricalis Geyer which I observed devouring a considerable portion of the wings of a dried Colias philodice Godart contained in the same collecting box. The caterpillar then proceeded to build a cocoon with what remained of the butterfly.

While this last case should really be classed as saprophagy, it should be noted that the remaining cases of cannibalism occurred under laboratory conditions rather than in nature. The reversion to a meat diet in many cases seemed to follow conditions of crowding or of lack of sufficient food. The following cases, especially the first, are offered to show that similar conditions can and undoubtedly do prevail in nature.

From October eleventh to November third 1937 I observed (Dedham, Mass.) an immense swarm of the larvæ of Isia isabella Smith \& Abbot which was estimated at not less than one hundred thousand. One could collect five hundred of these larvæ in three minutes without visibly decreasing the hordes covering the ground. The area thus overrun was 
marsh land, approximately half a square mile in extent, cut from north to south by a river, and bounded on all sides by highways. The larvæ were found only on the east side of the river. Of the thousands which were traveling back and forth between the river and the highway many were killed by passing vehicles and pedestrians. Practically every fifth caterpillar that had been killed was being eaten by one or more of the same species which were consuming all parts of the dead ones, except the hairs. The green vegetation in the vicinity was restricted to a narrow belt along each side of the highway. The scarcity of low-lying vegetation was evident. Practically the only green plant was an aster, Aster lævis, growing to a height of four feet. The larvæ which were not feasting on the dead specimens were eating the tops of the asters. Feeding on tall vegetation is unusual for a characteristically ground-loving species like Isia isabella. It is noteworthy that nearly all the larvæ showed signs of hunger. It would seem that the summer of 1937 was for some reason especially favorable to the development of this species. With the approach of autumn the supply of food plants in the area to which the caterpillars were confined gave out in the presence of such overwhelming numbers. The larvæ were prevented from traveling west by the river, hence they swarmed upon the highway where they were killed in large numbers. The hungry survivors either feasted upon the dead or climbed the asters. No cannibalism was observed in the few individuals of $D$. virginica and $E$. acræa which were also present.

On the occasion of an exceedingly large swarm of Ecpantheria, Orfila (1927) noticed three animals avidly devouring the remains of a fourth which was still living.

The following are also said to be cannibalistic in nature: Laphygma frugiperda Smith \& Abbot (Moore 1912), Vanessa caryæ Hb. (Berg 1875, 1892), and Heliothis obsoleta Fab. (Berg 1875, 1892). Berg reported that $H$. obsoleta ate from six to seven larvæ in twenty-four hours.

The question as to why larvæ show cannibalistic tendencies is a difficult one to answer. Three alternative solutions have been suggested by Orfila (1927) : 1) it is due to an internal physiological cause, 2) an organic disarrangement produces an alimentary upset, 3) cannibalistic manifestations herald 
a return to a past carnivorous diet. Orfila believes that the original diet was vegetable, and while he points out that sporadic cannibalism may be the forerunner of a more widespread carnivorous diet in the future, he leans toward the belief that cannibalism is due to an upset in internal organic conditions. Berg (1892) maintained that climatic conditions (in Patagonia) caused the supply of food plants to diminish so that larvæ were driven to cannibalism by hunger. This is undoubtedly correct. He further maintained, however, that the cannibalistic character was inherited, and that many larvæ could not return to a vegetable diet after having eaten meat. It is not improbable that natural selection could be responsible for the high percentage of cannibalism found in many species. I have observed, however, that our native species will return to a vegetable diet if given the opportunity. Schultz (1935) is of the opinion that cannibalism may be due not only to hunger but also to a need for satisfying thirst. Without a doubt thirst is a contributing factor. This much may be said, that cannibalism may be induced experimentally by crowding and by an insufficient food supply, but that it appears to crop out under conditions of favorable population densities and food supply as well. It is not improbable that this phenomonon will be found to be more widespread in lepidopterous larvæ than is realized at the present time. Thus far cannibalism has been reported in Geometridæ, Noctuidæ, Arctiidæ, Saturniidæ, Bombycidæ, Sphingidæ, Danaidæ, Nymphalidæ, Papilionidæ, Pieridæ, and Lycænidæ. It does not appear, however, that larvæ are forced to adopt a meat diet under favorable conditions but simply do so accidentally when in close proximity to another individual. Or, they may attack when unduly disturbed, and having tasted meat, continue to eat more or less automatically as long as its taste is not repellent. Larvæ taken off a meat diet will survive with no apparent ill effects on a normal vegetable diet.

\section{LITERATURE CITED}

Berg, C., 1875. Patagonische Lepidopteren. Bul. Soc. Imp. Nat. Moscou, 49(2): 191-193.

1892. Canibalismo entre insectos. Anal. Soc. Cient. Argentina, 34: 386-388.

Bird, H., 1925. New life histories in Papaipema No. 23 (Lepidoptera). Canadian Ent., 57(12) : 305. 
Brues, C. T., 1920. The selection of food plants by insects, with special reference to lepidopterous larvae. American Nat., 54: 313-332. 1936. Aberrant feeding behavior among insects and its bearing on the development of specialized food habits. Quart. Rev. Biol., 2(3) : 305-316.

Lederer, G., 1932. Tiere, die versuchten, sich selbst aufzufressen. Int. Ent. Zeit., 26(2) : 28.

Moore, H. W. B., 1912. Ways and habits of caterpillars. Timehri, 2(1) : $197,198$.

de Niceville, L., 1901. Cannibalism among caterpillars. Canadian Ent., $33(5)$ : $131,132$.

Orfila, R. N., 1927. Sobre canibalismo en insectos. Rev. Soc. Ent. Argentina, 2(4): 65, 66.

Perkins, R. C. L., 1928. Proc. Ent. Soc. London, 3(1) : 20.

v. Roesel v. Rosenhof, B., 1749. Insektenbelustigung Zweyte Classe der Nachtvögel, p. 82.

Schultz, V. G. M., 1928. Taeniocampa populi Ström. (= populeti Fr.) Int. Ent. Zeit., 21(46): 439-442.

1935. Lepidopterologische Beiträge. Einige Fälle von oophagem und chrysalidophagem Kannibalismus bei Grossschmetterlingsraupen. Int. Ent. Zeit., 28(41): 501-504, 556. 

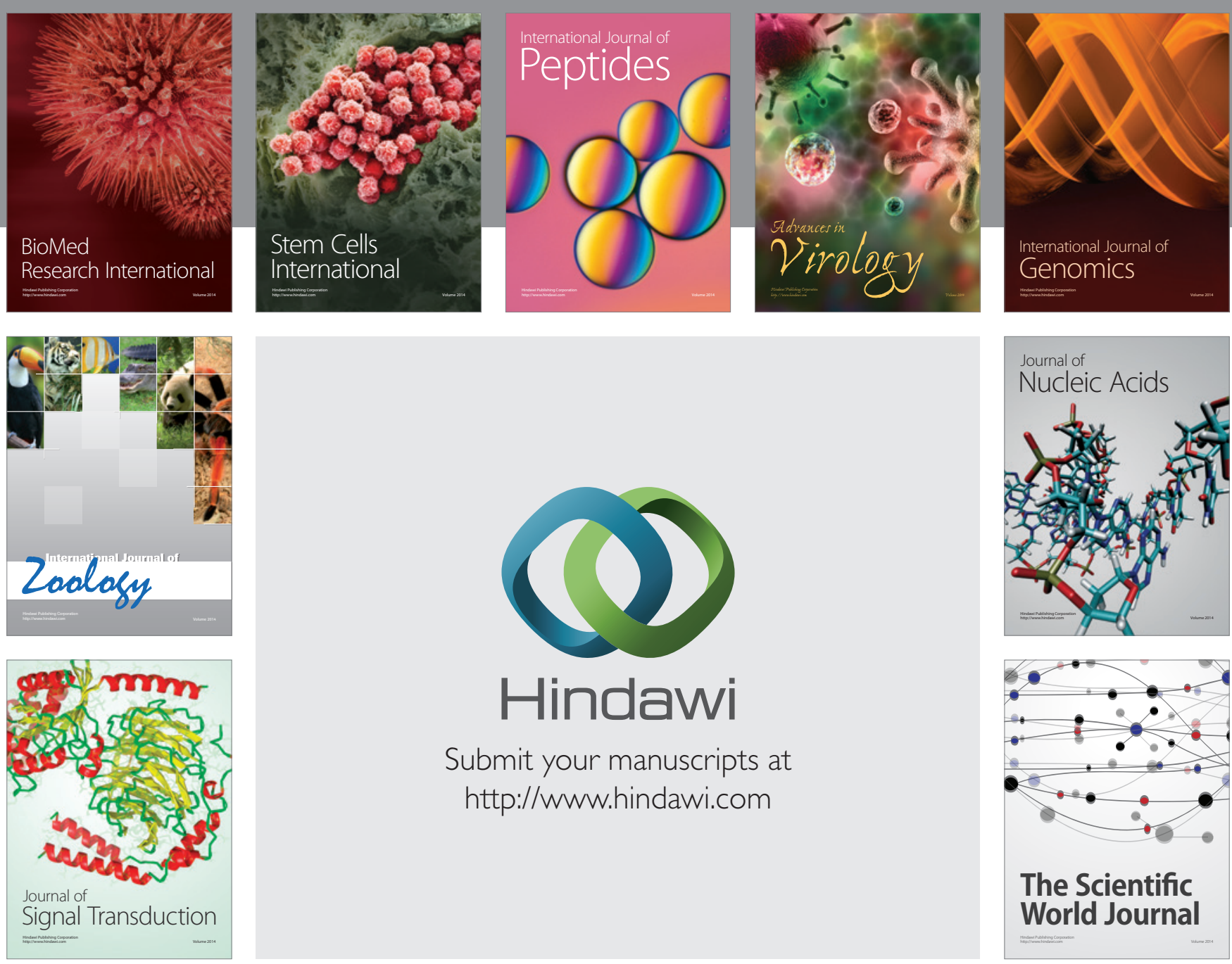

Submit your manuscripts at

http://www.hindawi.com
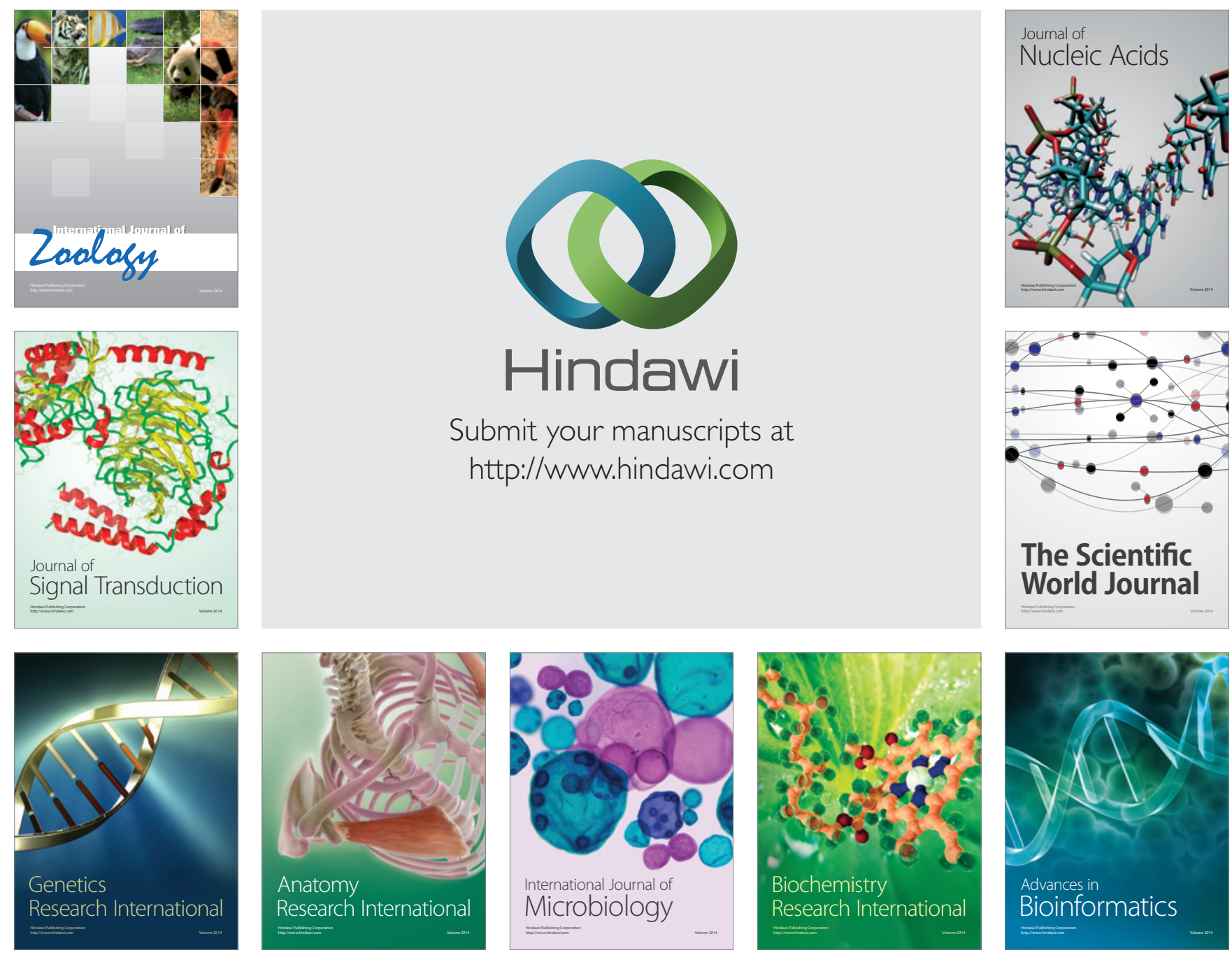

The Scientific World Journal
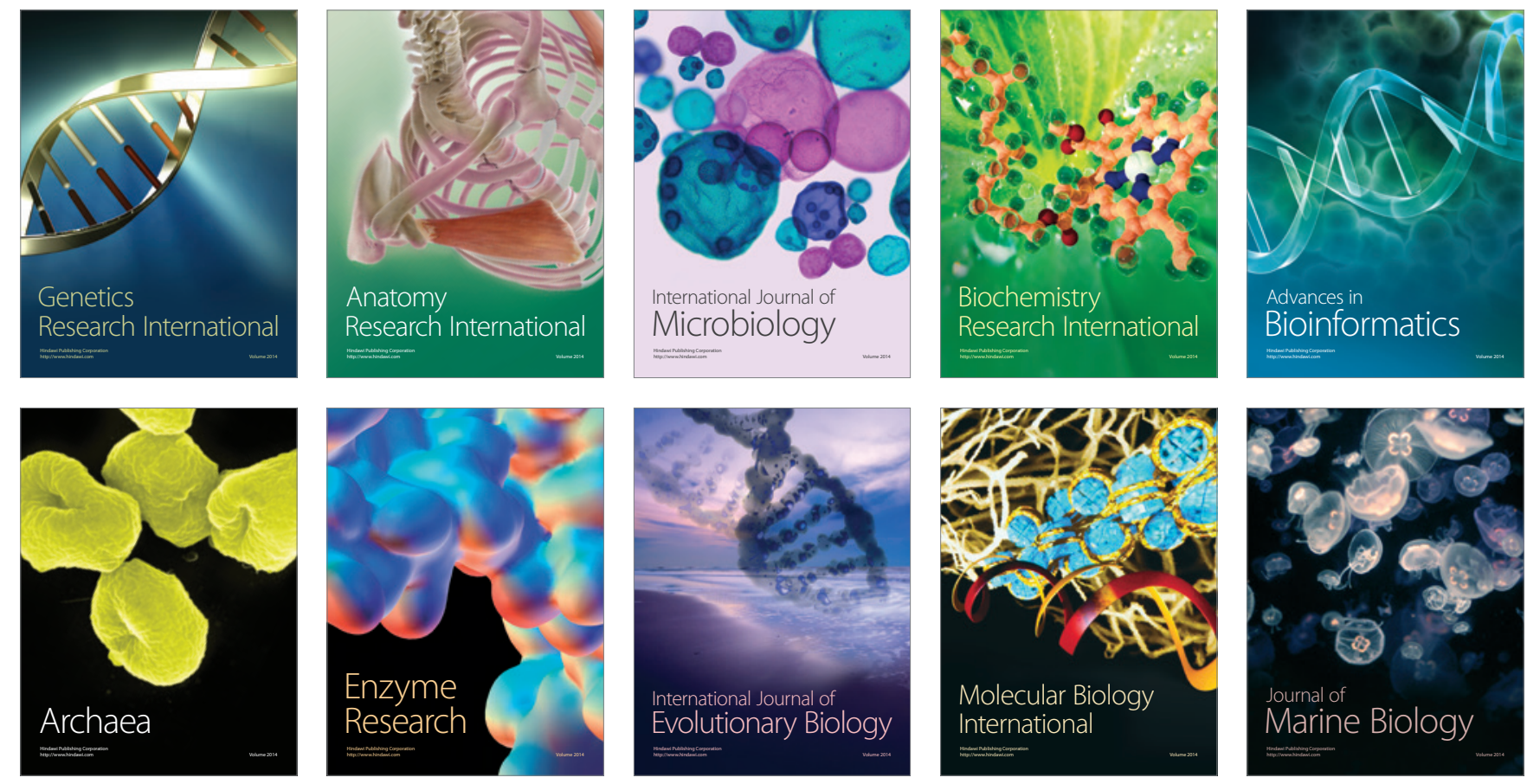